\title{
НОВЫЕ ДАННЫЕ О НАХОДКАХ РИМСКИХ АМФОР В ЧЕРНЯХОВСКОЙ КУЛЬТУРЕ
}

\author{
С. В. Диденко
}

\begin{abstract}
Діденко С. В. Нові дані про знахідки римських амфор у черняхівській культурі. Поселення пізньоримського часу Комарів на Середньому Дністрі характеризується великою кількістю знахідок фрагментів античних амфор. Більшість їх належить до типу Форлімпополі - рідкісних для Причорномор'я амфор з італійського узбережжя Адріатики. На пам'ятках черняхівської культури такий тип зафіксовано вперше. Ці амфори виготовлялися у I - на початку IV ст. н. е. на півночі Італії в регіоні Венето. Гончарні печі були відкриті на території міст Форлімпополі, Ріміні, Сантарканджело-ді-Романья.

Ключові слова: пізньоримський час; амфори; Форлімпополі; Італія; Комарів.
\end{abstract}

Диденко С. В. Новые данные о находках римских амфор в черняховской культуре. Поселение позднеримского времени Комаров на Среднем Днестре характеризуется большим количеством фрагментов античних амфор. Большинство из них принадлежит к типу Форлимпополи - редких для Причерноморья амфор из итальянского побережья Адриатики. На памятниках черняховской культуры такой тип тары зафиксирован впервые. Эти амфоры изготовлялись в I - начале IV вв. H. э. на севере Италии в регионе Венето. Гончарные печи были открыты на территории городов Форлимпополи, Римини, Сантарканджело-ди-Романья.

Ключевые слова: позднеримское время; амфоры; Форлимпополи; Италия; Комаров.

Didenko S. New Data on the Discoveries of Roman Amphorae in the Chernyakhov Culture. During the study of amphorae from the late Roman settlement Komariv, which is placed in the Middle Dniester, the big group of fragments was distinguished. This group presents rare for Northern Black Sea region Italic amphorae type. This type of antique containers was produced in northern Italy at the end of 1-beginning of 4 AD. Production centers are known in Forlimpopoli, Rimini and Santarcangelo di Romagna. The highest concentration of Forlimpopoli amphorae is noticed in the Veneto region.

Keywords: Late Roman Period; amphorae; Forlimpopoli; Italy; Komariv.

История ряда античных государств самым тесным образом связана с соседними варварскими племенами. Поэтому изучение контактов между античным и варварским мирами особенно важно для понимания политической или экономической ситуации в любом регионе древнего мира. В отдельных случаях находки античных изделий на варварских памятниках проливают свет на сложные процессы, происходившие на охваченных античной цивилизацией территориях. Особенно интересным в этом отношении является позднеримское время, когда политические и экономические контакты между северными провинциями Римской Империи и варварами Восточной и Центральной Европы достигли наивысшего расцвета.

Наибольшее количество находок предметов позднеантичного импорта зафиксировано в ареале черняховской культуры в III - начале V в., охватывающей обширные территории лесостепной и степной зон Украины, Молдовы и Трансильвании. Товары, главным образом вино в амфорах, поступали сюда из разных производственных центров Понтийского и Восточно-Средиземноморского регионов, а также из более отдаленных мест. Спрос на эти товары был большой и потому находки именно этой категории импорта наиболее многочисленные. На сегодняшний день в черняховской культуре известно более пятнадцати типов амфорной тары. Фрагменты амфор находят практически на каждом поселении, и количество этих находок возрастает по мере приближения к синхронным античным памятникам Северного Причерноморья.

В этом отношении один из наиболее высоких показателей зафиксирован на поселении у с. Комаров в Среднем Поднестровье, где на протяжении десяти полевых сезонов найдено свыше полутора тысяч фрагментов и шесть почти целых амфор. Это около 15-20\% от общего количества находок керамики на поселении, тогда как для других черняховских памятников украинской лесостепи этот показатель редко превышает 2\%1.

(C) Диденко, С. В., 2017 
Среди накопленного амфорного материала из Комарова выделяется группа фрагментов с одинаковым составом включений в глиняном тесте: визуально различимыми белыми макропримесями (более 0,8 мм) и частыми цветными микропримесями (менее 0,8 мм) черного, зеленоватого, желтоватого и серого цветов (Рис. 1, 2: 1, 2). Эти фрагменты имеют плотную структуру, розовый, розово-коричневый, светло-коричневый или красно-коричневый оттенки. На некоторых сохранился светлый ангоб. Стенки гладкие или с неглубоким рифлением. Профильные фрагменты давали некоторое пред-

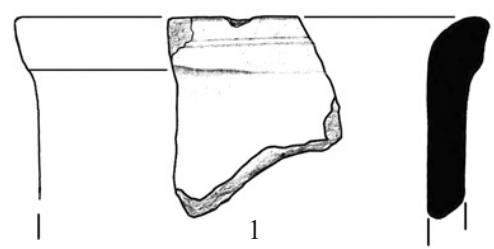

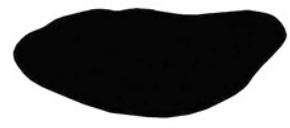

2

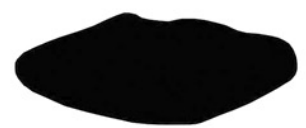

4

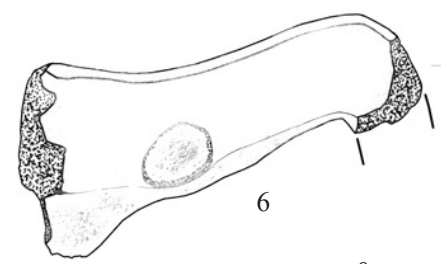

0
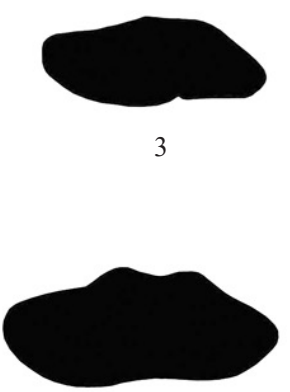

5

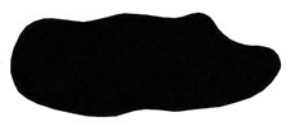

$5 \mathrm{~cm}$
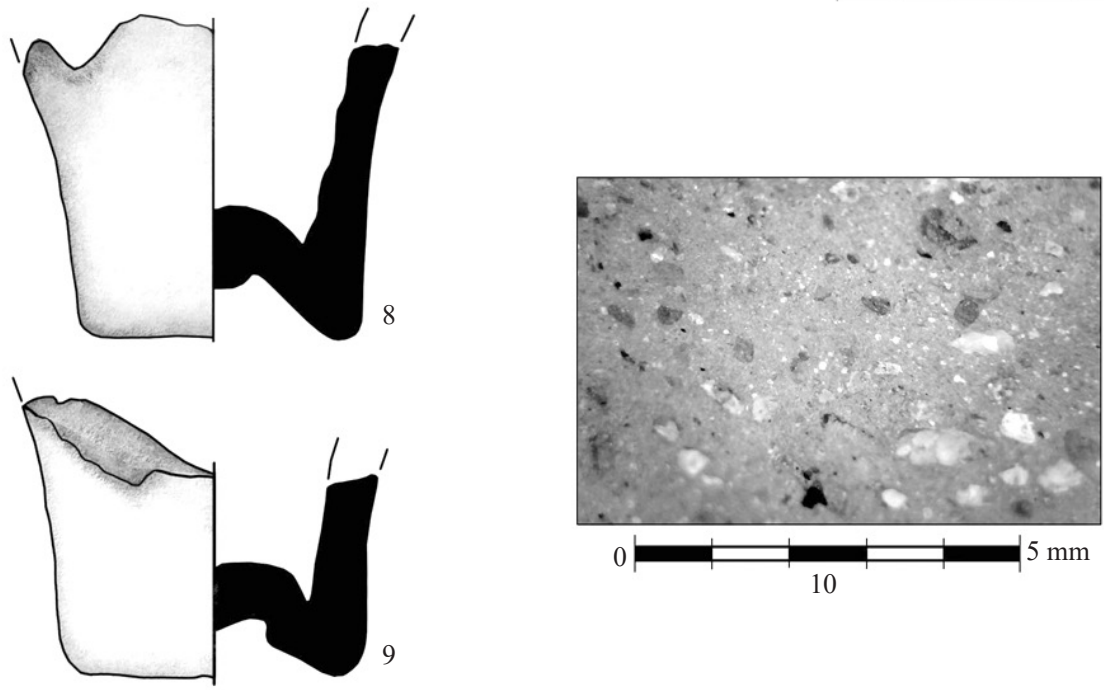

10

Рис. 1. Фрагменты амфор типа Форлимпополи из культурного слоя поселения Комаров (Рис. С. В. Диденко) 
ставление о форме этих сосудов: узкое цилиндрическое горло, широкие уплощенные и изогнутые под острым углом ручки, яйцевидный корпус, низкие узкие ножки с вогнутой подошвой. Из-за крайней фрагментарности первые попытки идентификации этой группы материала оказались безуспешными. Тара с такими характеристиками отсутствовала в публикациях материалов античных городов Северо-Западного Причерноморья и Крыма, которые считаются посредниками в римско-варварской торговле. Но благодаря материалам, полученным в ходе раскопок Комаровского поселения в 2014 г., она все же была идентифицирована, оказавшись ранее неизвестным в черняховской культуре типом античной керамической тары.

Находки из Комарова принадлежат к так называемому типу Форлимпополи - редких для Причерноморья амфор из итальянского побережья Адриатики. Эти амфоры были выделены в отдельный тип Тобией Альдини в 1978 г. в процессе исследований на территории г. Форлимпополи (римский Forum Popili) в нынешней провинции Эмилиа-Романья на севере Италии, где были открыты гончарные печи для их обжига, а также многочисленные ямы с керамическим браком, развалами и отдельными обломками этих сосудов ${ }^{2}$. Позднее следы их производства фиксировались на территории городов Римини и Сантарканджелоди-Романья того же региона на юго-восток от Форлимпополи ${ }^{3}$.

T. Альдини разделила этот тип на варианты A, B, C, D, отличающихся между собой некоторыми деталями. Объединяет их яйцевидное тулово, узкое горло и широкие изогнутые под острым углом профилированные ручки. Проследить хронологию эволюции типа на базе выделенных вариантов не удалось вследствие малого количества узко датированных комплексов с этими амфорами ${ }^{4}$. Однако можно утверждать, что их производство в целом продолжалось с последней четверти I до начала IV в. н. э. ${ }^{5}$.

Амфоры типа Форлимпополи лишены клейм или dipinti, что затрудняет решение вопроса о перевозившихся в них продуктах. Л. Каккиагуэрра, изучившая органические остатки на стенках амфор в музее г. Форлимпополи, пришла к выводу, что они были полифункциональными и предназначались для транспортировки различных продуктов питания, изготовленных в районе Падуйской низины ${ }^{6}$. Однако большинство исследователей считает, что основным продуктом, перевозившимся в этих сосудах, было вино 7 .

Наибольшая концентрация находок амфор типа Форлимпополи наблюдается вблизи центров их производства в регионе Венето на севере Италии ${ }^{8}$. Они зафиксированы в Аквилее $^{9}$, на о. Торчелло и в Лио Пикколо (Венецианский залив) ${ }^{10}$. Целые экземпляры хранятся в археологических музеях городов Портогруаро, Конкордия-Саджиттария, Каорле, Одерцо, Адрии, коллекции которых формировались преимущественно на материалах местных исследований. Известны они и в предгорьях Альп в Вирунуме ${ }^{11}$.

Т. Альдини первой выразила мысль о том, что продукция в указанных амфорах предназначалась не только для североиталийских рынков сбыта ${ }^{12}$, что подтверждается находками из ряда памятников Центральной и Южной Италии - Остии ${ }^{13}$, Помпей ${ }^{14}$, Альтино ${ }^{15}$, Апулийской области ${ }^{16}$. Эти амфоры присутствовали среди товаров нескольких кораблей, затонувших вблизи восточного побережья Адриатики (кораблекрушения в районе островов Вис, Иловик и Шольта у берегов Хорватии $)^{17}$. Зафиксирована их транспортировка и на более отдаленные рынки Средиземноморья - в Сардинию (Порто Торрес), Афины ${ }^{18}$, на Крит ${ }^{19}$, в Северную Африку (Типаза, Эль-Джем, Бенгази, Лептис Магна, Фарас, Мероэ) ${ }^{20}$.

Значительная часть находок амфор типа Форлимпополи происходит из римских дунайских провинций: Паннонии, Верхней и Нижней Мезии (Сингидунум, Виминаций, Трансдиерна, Диана, Понтес, Истрия, Троэзмис), Дакии (Ромула Мальва) ${ }^{21}$. Семь экземпляров были среди материалов кораблекрушения на Дунае у с. Батин в Болгарии ${ }^{22}$.

Таким образом, помимо локального распространения в италийских провинциях, существуют два основных направления распространении амфор типа Форлимпополи: морской средиземноморский (к берегам Сардинии на западе, африканского побережья на юге, Афин и Крита на востоке) и речной или сухопутный дунайский, по которому проходили товарные потоки из Западной Европы к Западному Причерноморью. При этом самая большая их концентрация наблюдается в среднем и нижнем течении Дуная, включая современную Добруджу. Не исключено, что италийское вино в этих амфорах преимущественно предназначалось для контингента римских гарнизонов Дунайского лимеса. 
Доходя до городов западного побережья Черного моря, амфоры типа Форлимпополи по каким-то причинам не поставлялись в Южное и Восточное Причерноморье. Возможно, это объясняется серьезной конкуренцией в тогдашней винной торговле, поскольку виноделы Гераклеи Понтийской, Синопы и Колхиды сами были крупнейшими поставщиками этого продукта на причерноморские и средиземноморские рынки. Похожая ситуация наблюдается и на северном побережье Понта: амфоры типа Форлимпополи пока не известны в Тире, Ольвии, Херсонесе, городах Европейского и Азиатского Боспора.

Тем более неожиданным является факт их находок в Танаисе (Рис. 2: 3-5). В силу особенных исторических условий, связанных с рядом катастроф, которым подвергался этот город с конца I до середины III вв. н. э., в Танаисе образовались закрытые комплексы с огромным количеством целых форм различных типов амфор, бытовавших одновременно. В первую очередь к таким относятся склады танаисских купцов, надежно датирующиеся по монетам, стеклянной и краснолаковой посуде. Большая часть их погибла во время разгрома варварами в середине III в. Материалы из этих комплексов опубликованы в ряде работ ${ }^{23}$. В частности, амфорам типа Форлимпополи посвящены специальные публикации С. А. Науменко и К. Пачыньской, где приводится развернутая характеристика этого типа тары $^{24}$. На 2001 год из раскопок Танаиса было известно 6 целых и 82 фрагмента амфор типа Форлимпополи (20 венчиков, 13 горл, 30 ручек, 19 ножек).

Самыми близкими для Танаиса рынками, где можно было бы приобрести продукцию в этой таре, были западнопричерноморские порты. Отсутствие этих амфор на других античных памятниках региона может говорить о том, что торговля между Танаисом и городами Западного Причерноморья вряд ли была транзитной, а перевозкой товаров занимались именно танаиты для их реализации исключительно на своих рынках. В противном случае западнопричерноморские торговцы, направляясь со своим товаром в Танаис, вряд ли обходили бы Тиру, Ольвию и города Крымского побережья.

Так или иначе, самая большая концентрация амфор типа Форлимпополи в северопонтийском регионе пока наблюдается лишь в Танаисе и Комарове. Напомним, что коллекция амфорной тары из Комарова насчитывает сотни фрагментов этого типа, причем они составляют абсолютное большинство (около 90\%) керамического импорта, поступавшего сюда в III - начале IV в.

Возникает вопрос, каким образом значительное количество амфор типа Форлимпополи попадало вглубь варварских территорий? Дальнейшее исследование показало, что за границами античного мира известно еще несколько местонахождений этих сосудов, а именно: погребение 1 кургана 5 позднесарматского могильника Чауш ${ }^{25}$ (Рис. 3: 1), погребение в кургане 1 могильника культуры карпатских курганов Бранешты-Немцишор ${ }^{26}$ (Рис. 3: 2), погребение в кургане 2 могильника этой же культуры Каминна ${ }^{27}$ (Рис. 3: 3) и случайная находка целой амфоры у с. Негин Хмельницкой обл. (Рис. 3: 4). Могильник Чауш (с. Новосельское Одессой обл.) находится в дельте Дуная рядом с Новосельской переправой. Памятник расположен практически на дунайском пути транспортировки амфор типа Форлимпополи в Западное Причерноморье напротив римского города Троэзмис, где находки этих сосудов известны. По данным А. В. Симоненко, комплекс датируется концом III - началом IV в. ${ }^{28}$. Могильник Бранешты-Немцишор (область Пятра Нямц) находится в бассейне р. Сирет в восточных отрогах румынских Карпат, а могильник Каминна - в Верхнем Поднестровье, неподалеку от истоков р. Прут. Село Негин находится в 45 км от Комарова на противоположном берегу Днестра в долине р. Смотрич.

Так как амфоры типа Форлимпополи пока не найдены в нижнем течении Днестра, именно находки из упомянутых памятников маркируют путь их поступления в Комаров долинами Прута или Сирета. Впадая в Дунай в его нижнем течении, эти реки связывают Прикарпатье и Буковину с Добруджей, которая с I в. была частью провинции Нижняя Мезия, а после административной реформы Диоклетиана в конце III в. - провинции Малая Скифия. Роль римских городов Добруджи как торговых центров тяжело переоценить. На их рынки стекались товары из западных и балкано-дунайских провинций, Малой Азии, Северного и Восточного Средиземноморья. Поэтому практически не возникает сомнений, что большинство импортной продукции поступало к варварам Прикарпатья и Буковины именно из Добруджи. К тому же, напротив впадения в Дунай Прута и Сирета располагалась Диногеция - римский город-крепость на границе Империи и важное место 

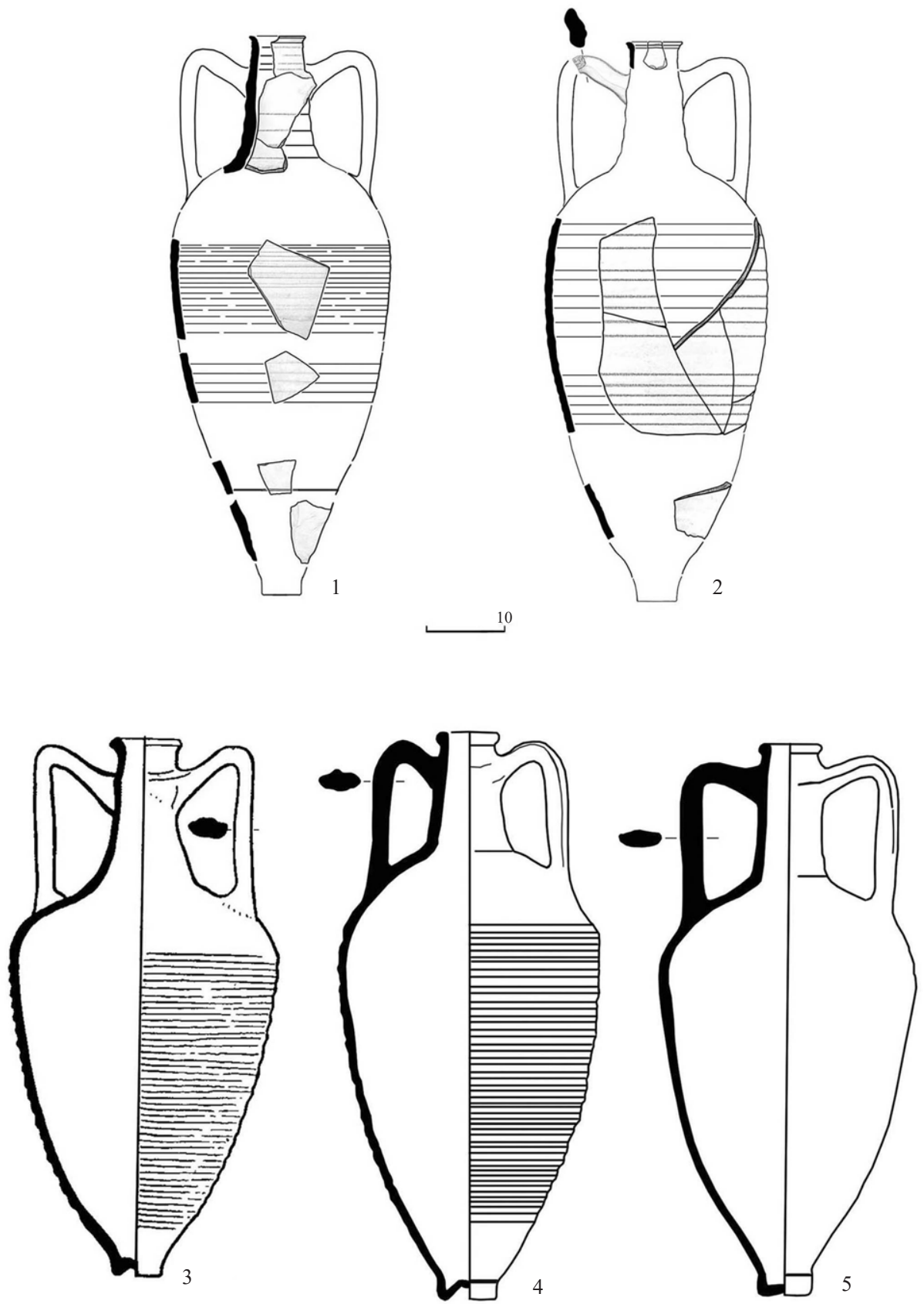

Рис. 2. Амфоры типа Форлимпополи: 1, 2 - Комаров (объекты 13 и 19) (реконструкции С. В. Диденко); 3-5 -Танаис (Брашинский И. Б. Торговля // Античные государства Северного Причерноморья. Москва, 1984. Табл. LXXIV: 6; Арсеньева T. М., Науменко С. А. Усадьбы Танаиса. Москва, 1992. Рис. 27: 2; Naumienko S., Paczyńska K. Importy amfor typu Forlimpopoli do Tanais w II i III wieku n. e. // Światowit. 2001. № 3. Fig. 6) 

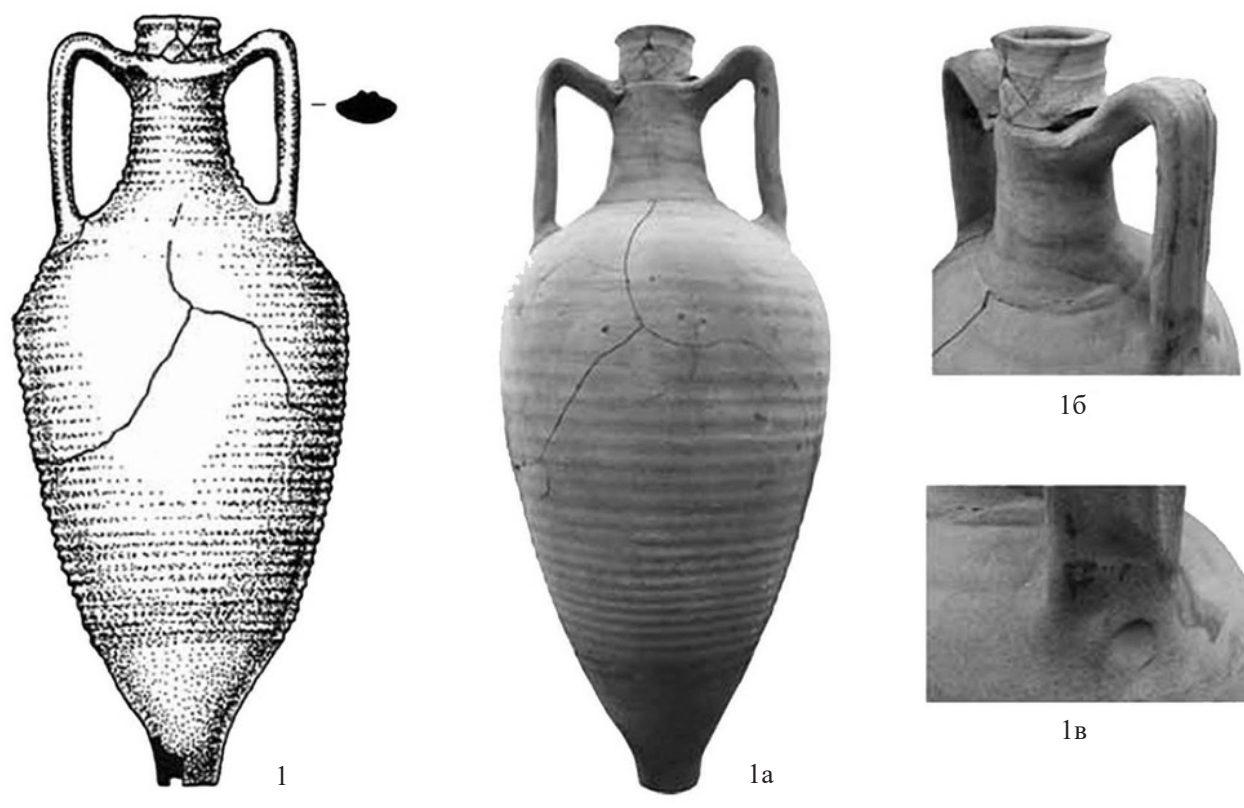

16

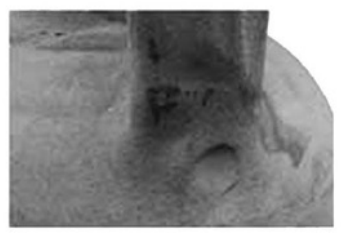

1в
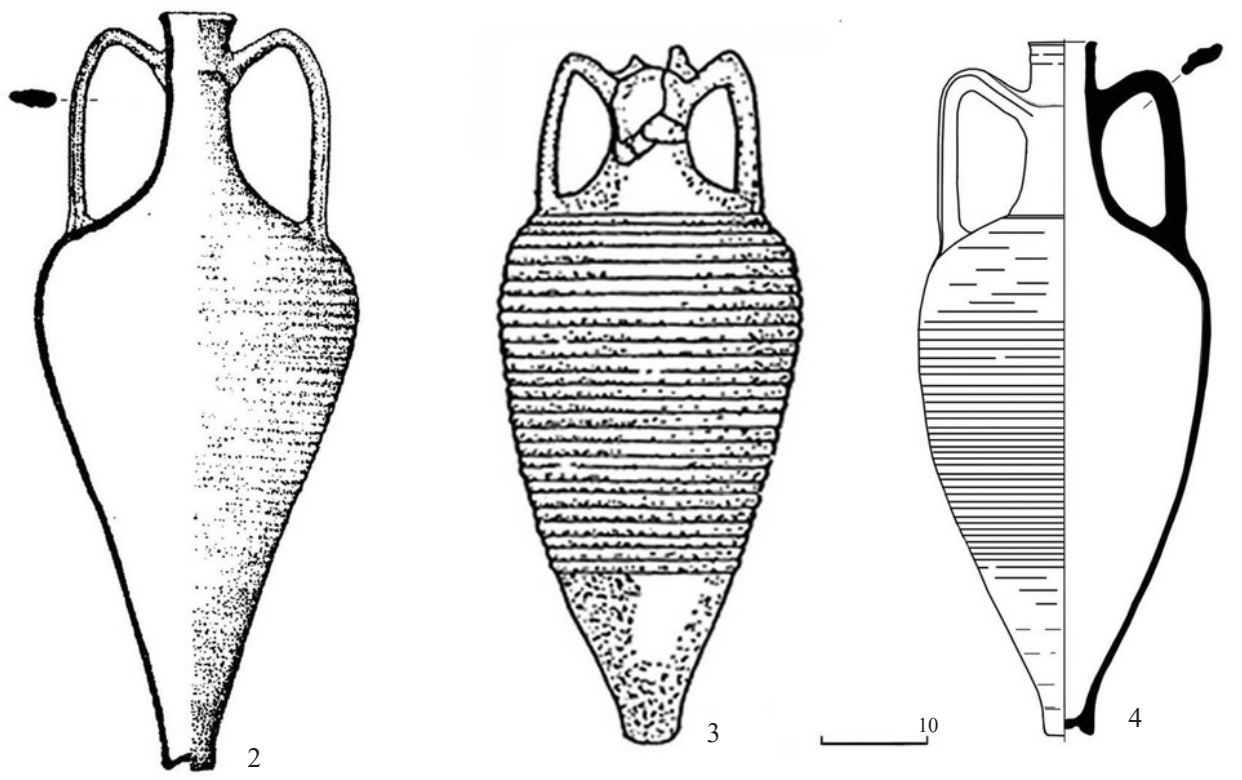

Рис. 3. Амфоры типа Форлимпополи: 1 - Чауш, курган 5, погребение 1 (Симоненко А. В. Римский импорт у сарматов Северного Причерноморья. Санкт-Петербург, 2011. Рис. 88: 5; 89); 2 - БранештыНемцишор, курган 1 (Mihailescu-Bîrliba $V$. Un nouveau groupe culturel sur le territoire de Roumanie. Les fouilles de Braniște-Nemțişor (comm. de Vînători, dép. de Neamţ) // Dacia. 1980. Vol. XXIV. Fig. 22); 2 - Каминна, курган 2 (Вакуленко Л. В. Українські Карпати у пізньоримський час (етнокультурні та соціально-економічні процеси). Київ, 2010. Рис. 68: 4); 3 - Негин (Рис. С. В. Диденко) 
торговли с северными племенами ${ }^{29}$. Именно Диногеция наилучшим образом претендует на роль пункта, из которого италийское вино в амфорах типа Форлимпополи по долинам Прута или Сирета через Прикарпатье направлялось в Комаров. Причем, материалы памятника свидетельствуют в пользу прямых поступлений партий этого вина. Не исключено, что катализатором массовых поставок италийского вина в Комаров стал разгром Танаиса в 250-х гг, который до этого был главным потребителем данного продукта в Северном Причерноморье. Так или иначе, но факт присутствия амфор типа Форлимпополи в Танаисе и на Комаровском поселении является исключительным явлением для северной периферии античного мира и Европейского Барбарикума и требует внимательного дальнейшего изучения.

${ }^{1}$ Петраускас O. В. Деякі підсумки досліджень комплексу пам'яток пізньоримського часу біля с. Комарів // OIUM. 2014. Вип. 4. С. 165-183; Діденко С. В. Дунайські амфори з поселення пізньоримського часу Комарів // LAUREA I. Античный мир и Средние века: Чтения памяти профессора Владимира Ивановича Кадеева. Материалы. Харьков, 2015. С. 23-27.

${ }^{2}$ Aldini T. Anfore foropopiliens // Archeologia Classica. 1978. Vol. XXX. P. 236-245; pl. 89-91.

${ }^{3}$ Maioli M. G., Stoppioni M. Anfore di produzione romagnola // Amphores romaines et histoire économique: dix ans de recherché. Roma, 1989. P. 574.

${ }^{4}$ Aldini T. Anfore foropopiliens // Archeologia Classica. 1978. Vol. XXX. P. 244; Aldini T. Fornaci di Forum Popili. Forlimpopoli, 1981. 137 p.; Aldini T. Nuovi dati sulle anfore forolimpopilensi // Studi Romagnoli. 1989. P. 348-418; Aldini T. Elementi per una più coretta classificazione delle anfore forlimpopolensi // Atti e memorie. Nuova Serie. 1996. P. 11-22; Aldini T. Anfore foropopiliensi in Italia // Documenti e studi. 1999. Vol. 10. P. 23-56.

${ }^{5}$ Aldini T. Anfore foropopiliens // Archeologia Classica. 1978. Vol. XXX. P. 244; Maioli M. G., Stoppioni $M$. Anfore di produzione romagnola // Amphores romaines et histoire économique: dix ans de recherché. Roma, 1989. P. 574; Panella C. Le anfore italiche dell II secolo d. C // Amphores romaines et histoire economique: dix ans de recherche. Roma, 1989. P. 153; Cipriano M. T., Carre M. B. Production et typologie des amphores sur la côte adriatique de l'Italie // Amphores romaines et histoire йconomique: dix ans de recherche. Roma, 1989. P. 88; Sciallano M., Sibella P. Amphores, comment les identifier?. Aix-en-Provence, 1991. P. 39.; Dyczek P. Amfory rzymskie z obzaru dolnego Dunaju: dystrybucja amfor i transportowanych w nich produktow w I-III w. po Chr. Warszawa, 1999. P. 67, 68; Riley J. A. The Coarse Pottery from Berenice // Excavations at Sidi Khrebish Benghazi (Berenice). Tripoli, 1979. Vol. II. P. 197.

${ }^{6}$ Cacciaguerra L. Anfore e commerci nella Venetia. Dalle anfore elementi utiliper la storia del Veneto Orientale tra il III secolo avanti Cristo e il VI secolo dopo Cristo. Portogruaro, 1990. P. 13, 14; Cacciaguerra L. Anfore foropopiliensi nel Veneto Orientale // Documenti e Studi. 1991. Vol. II. P. 34.

${ }_{7}$ Maioli M. G., Stoppioni M. Anfore di produzione romagnola // Amphores romaines et histoire économique: dix ans de recherché. Roma, 1989. P. 575; Panella C. Le anfore italiche dell II secolo d. C. // Amphores romaines et histoire economique: dix ans de recherche. Roma, 1989. P. 154-156; Sciallano M., Sibella P. Amphores, comment les identifier?. Aix-en-Provence, 1991. P. 38; Dyczek P. Amfory rzymskie z obzaru dolnego Dunaju: dystrybucja amfor i transportowanych w nich produktow w I-III w. Po Chr. Warszawa, 1999. S. 67; Mordzewska I. X Regio augustejskie ipozaalpejskie szlaki handlowe // Światowit. 1999. № 1, fasc. A. S. 106.

${ }^{8}$ Cacciaguerra L. Anfore e commerci nella Venetia. Dalle anfore elementi utiliper la storia del Veneto Orientale tra il III secolo avanti Cristo e il VI secolo dopo Cristo. Portogruaro, 1990. P. 12, 13; Cacciaguerra L. Anfore foropopiliensi nel Veneto Orientale // Documenti e Studi. 1991. Vol. II. P. 21-36.

${ }^{9}$ Carre M. B. Les amphores de la Cisalpin et de l'Adriatique au début de l'Empire // Merfa. 1985. № 97, fasc. 1. P. 228-231; fig. 5; Cipriano M. T., Carre M. B. Production et typologie des amphores sur la côte adriatique de l'Italie // Amphores romaines et histoire йconomique: dix ans de recherche. Roma, 1989. P. 486; fig. 17; Verzâr-Bass M. Scavi di Aquileia I: L'area a est del foro. Rapporto degli scavi 1989-91 // Studi e ricerche sulla Gallia Cisalpina. 1994. Vol. 6. P. 385-389; pl. 59

${ }^{10}$ Mordzewska I. Sulla storia della laguna di Venezia nell’Antichità // Światowit. 2000. № 4. Supplement Series A: Antiquity. P. 50, 61; Leciejewicz L., Tabaczyńska E., Tabaczyński S. Torcello: Scavi 1961-62; Istituto Nacionale di Archeologia e Storia dell'Arte. Roma, 1977. 566 p.

${ }^{11}$ Mordzewska I. X Regio augustejskie ipozaalpejskie szlaki handlowe // Światowit. 1999. № 1, fasc. A. S. 106.

${ }_{12}$ Aldini T. Anfore foropopiliens // Archeologia Classica. 1978. Vol. XXX. P. 245.

${ }^{13}$ Manacorda D. Ostia IV, Le anfore // Studi Miscellanei. 1977. Vol. 23. P. 371, 372; pl. 54, 440-442; 84, 632-634; Panella C. Le anfore italiche dell II secolo d. C. // Amphores romaines et histoire economique: dix ans de recherche. Roma, 1989. P. 146-156; Aldini T. Anfore foropopiliens // Archeologia Classica. 1978. Vol. XXX. P. 245. 
${ }^{14}$ Hayes J. W. The villa Dionysos excavations, Knossos: The pottery // British School at Athens (далее - BSA). 1983. № 78. P. 145.

${ }^{15}$ Cacciaguerra L. Anfore e commerci nella Venetia. Dalle anfore elementi utiliper la storia del Veneto Orientale tra il III secolo avanti Cristo e il VI secolo dopo Cristo. Portogruaro, 1990. P. 12, 13; Cacciaguerra L. Anfore foropopiliensi nel Veneto Orientale // Documenti e Studi. 1991. Vol. II. P. 21-36.

${ }^{16}$ Volpe G. La Daunia nell'età della romanizzazione. Paesaggio agrario, produzione, scambi. Bari, 1990. P. 228.

${ }_{17}$ Matejčić R. Petnaest godina hidroarheoloških istraživanja u Kvarneru // Pomorski zbornik. 1976. № 14. P. 351, 352; Orlić M. Podmorsko arheološko nalazište Ilovik // Arheološka istraživanja na otocima Cresu i Lošinju (Mali Lošinj. 1979). Zagreb, 1982. P. 153; Parker A. J. Ancient Shipwrecks on the Mediterranean \& the Roman Provinces // British Archaeological Reports (далеe - BAR) International Series. 1992. Vol. 580. P. 215, 230, 277, 278; nr. 513, 558, 792.

${ }^{18}$ Robinson H. S. Pottery of the Roman Period: Chronology. Princeton-New-Jersey, 1959. (The Athenian Agora; vol. V). P. 69; pl. 15, K 114.

${ }^{19}$ Hayes $J$. $W$. The villa Dionysos excavations, Knossos: The pottery // BSA. 1983. № 78. P. 145, type 7.

${ }^{20}$ Riley J. A. The Coarse Pottery from Berenice // Excavations at Sidi Khrebish Benghazi (Berenice). Tripoli, 1979. Vol. II. P. 197, typ MR 13; fig. 85, 256; Panella C. Le anfore italiche dell II secolo d. C. /I Amphores romaines et histoire economique: dix ans de recherche. Roma, 1989. P. 150; Paczyńska K., Naumenko S. Forlimpopoli Amphorae at Tanais in the Second and Third Centuries AD // Transport Amphorae and Trade in the Eastern Mediterranean: Acts of International Colloquium at the Danish Institute at Athens, 26-29 September, 2002. Oxford, 2004. P. 311, note 27.

${ }^{21}$ Plesničar-Geg L. Keramika emonskich nekropola // Dissertationes et monographiae. 1977. Vol. XX. pl. 8; Brukner O. Rimska keramika u Jugoslovenskom Delu Provincije Donje Pannonije. Beograd, 1981. pl. 165-167; Bjelajac L. Amfore gornjo mezijskog Podunavlja. Beograd, 1996. P. 22-25; fig. 4; Opait A. Consideraţii preliminare asupra amforelor romane și romano-byzantine din Dobrugea // Peuce. 1980. Vol. 8. P. 304; Suceveanu A. Les thermes romains. Bucarest, 1982. P. 104; pl. 10.

${ }^{22}$ Popilian G. Ceramika Romana dîn Oltenia. Craiova, 1976. P. 46; pl. 16, 208-213; Dyczek P. Amfory rzymskie z obzaru dolnego Dunaju: dystrybucja amfor i transportowanych w nich produktow w I-III w. po Chr. Warszawa, 1999. P. 66.

${ }^{23}$ Брашинский И. Б. Торговля // Античные государства Северного Причерноморья (Археология CCCP). Москва, 1984. табл. LXXIV: 6; Арсеньева T. М. Усадьбы Танаиса. Москва, 1992; Арсеньева Т. М., Науменко С. А. Комплекс находок из подвала МБ II-ІІІ вв. н. э. // Вестник Танаиса. Ростов-на-Дону, 1994. Вып. 1. С. 61-139; Науменко С. А. Амфоры из закрытых комплексов Танаиса середины III в. н. э. // Первая Абхазская международная археологическая конференция. Сухум, 2006. С. 261-267; Науменко С. А. Амфоры из закрытых комплексов Танаиса римского времен // Novensia: studia i materially. Warszawa, 2008. Vol. 18-19. S. 267-289; Науменко С. А. Состав амфор в закрытых комплексах Танаиса конца I - середины ІІІ вв. н. э. // Вестник Танаиса. Ростов-на-Дону. 2012. Вып. 3. C. 63-88; Naumenko S. A. Trade relations between Tanais and the Pontic region // The Bosporus: Gateway between the Ancient West and East (1st Millennium BC - 5th Century AD): proceedings of the Fourth International Congress on Black Sea Antiquities Istanbul, 14th-18th September 2009 / BAR International Series 2517. Oxford, 2013. P. 103-108.

${ }^{24}$ Naumienko S. Importy amfor typu Forlimpopoli do Tanais w II i III wieku n. e. / S. Naumienko, K. Paczyńska // Światowit. 2001. № 3 S. 165-174; Paczyńska K. Forlimpopoli Amphorae at Tanais in the Second and Third Centuries AD / K. Paczyńska, S. Naumenko // Transport Amphorae and Trade in the Eastern Mediterranean. Vol. 5. 2004. P. 309-312.

${ }_{25}$ Симоненко А. В. Римский импорт у сарматов Северного Причерноморья. Спб.: НесторИстория, 2011. С. 147,148 ; рис. $88,89$.

${ }^{26}$ Mihailescu-Bîrliba $V$. Un nouveau groupe culturel sur le territoire de Roumanie. Les fouilles de Branişte-Nemţişor (comm. de Vînători, dép. de Neamț) // Dacia. 1980. Vol. XXIV. P. 202; fig. 22.

${ }^{27}$ Majewski K. Importy rzymskie na ziemiach slowiańskich. Wroclaw, 1949. tabl. X, fig. 5; Кропоткин В. В. Римские импортные изделия в Восточной Европе // Свод археологических источников. 1970. Вып. Д. 1-27. С. 48; рис. 33: 6; Вакуленко Л. Українські Карпати у пізньоримський час (етнокультурні та соціально-економічні процеси). Київ, 2010. С. 126; рис. 68: 4.

${ }_{28}$ Симоненко А. В. Римский импорт у сарматов Северного Причерноморья. Спб.: НесторИстория, 2011. С. $147,148$.

${ }^{29}$ Barnea I. Dinogetia, une ville byzantine du Bas-Danube // Byzantina. 1980. Vol. 10. P. 5-238. 